İşletme Akademisi Dergisi
2020, $1(2): 125-142$
DOI:10.2677/TR 1010.2020 .436
Dergi web sayfasi: www.sakder.org

Araștırma Makalesi

\title{
Muhasebede Hata ve Hilelerin Meslek Etiği Açısından İncelenmesi: Erzincan İli Örneği
}

\author{
Dr. Öğr. Üyesi Ersin KURNAZ \\ Erzincan Binali Yıldırım Üniversitesi, İktisadi ve İdari Bilimler Fakültesi, Sağllk Yönetimi \\ Bölümü, Erzincan \\ ersinkurnaz2429@gmail.com, https://orcid.org/0000-0002-6787-5368
}

\section{Sena Nur KARADOĞAN}

Erzincan Binali Yıldırım Üniversitesi, Sosyal Bilimler Enstitüsü, İşletme Bölümü, Erzincan, karadogansenanur@gmail.com, https://orcid.org/0000-0002-5912-0563

Öz

$\mathrm{Bu}$ çalışmada, muhasebede hata ve hilelerin meslek etiği açısından değerlendirilmesi ve muhasebe meslek mensuplarının söz konusu hususlara ilişkin görüşlerinin ortaya konulması amaçlanmıştır. Ayrıca muhasebede hata ve hilelerin nedenlerini ve muhasebe meslek mensuplarını hata ve hile yapmaya yönelten etkenlerin neler olduğunu belirlemek çalışmanın bir diğer amacını oluşturmaktadır. Bu kapsamda, Erzincan'daki Serbest Muhasebeci Mali Müşavirler Odası'na kayıtlı muhasebe meslek mensuplarına bir anket uygulanmıştır. Anketlerden elde edilen veriler, SPSS programı yardımıyla frekans ve yüzde gibi tanımlayıcı istatistiklerin yanı sıra Kruskal-Wallis Testi ile analiz edilmiştir. Araştırma sonucunda, muhasebe meslek mensupları yapılan hataların nedenini iş yoğunluklarına bağladıkları görülmüştür. Ayrıca mevcut denetim sistemi ve vergi uygulamalarının muhasebede hata ve hilelerin önüne geçmede yeterince etkili olmadığı ve merkezi bir etik kurulunun kurulması gerektiği ifade edilmiştir. Son olarak muhasebe meslek mensuplarının tecrübeleri ile muhasebede hata, hile ve meslek eğitine yönelik düşünceleri ve karşılaştıkları hata ve hileler arasında anlamlı bir farklılık tespit edilmiştir.

Anahtar Kelimeler: Muhasebe, Hata, Hile, Meslek Etiği.

Makale Gönderme Tarihi: 30.04.2020

Makale Kabul Tarihi: 26.05.2020

\section{Önerilen Atıf:}

Kurnaz, E. ve Karadoğan, S. N., (2020). Muhasebede Hata ve Hilelerin Meslek Etiği Açısından İncelenmesi: Erzincan İli Örneği, İşletme Akademisi Dergisi, 1(2): 125-142.

(C) 2020 İşletme Akademisi Dergisi. 


Journal of Business Academy
$2020,1(2): 125-142$
DOI:10.26677/TR1010.2020.
Web pages: www.isakder.org

$\underline{\text { Research Article }}$

\title{
Investigatin of Errors and Fraud in Accounting in terms of Professional Ethics: Case of Erzincan Province
}

\author{
Asst. Prof. Ersin KURNAZ \\ Erzincan Binali Yıldırım University, Faculty of Economics and Administrative Sciences, \\ Administration of Health Institutions, Erzincan \\ ersinkurnaz2429@gmail.com, https://orcid.org/0000-0002-6787-5368
}

\section{Sena Nur KARADOĞAN}

Erzincan Binali Yıldırım University, Institutes of Social Sciences, Department of Business Management, Erzincan

karadogansenanur@gmail.com, https://orcid.org/0000-0002-5912-0563

\begin{abstract}
In this study, it is aimed to evaluate the errors and frauds in terms of professional ethics and to reveal the opinions of professional accountants on these issues. In addition, it is another purpose of the study to determine the causes of errors and fraud in accounting, and what factors lead to errors and fraud. In this context, a questionnaire was applied to professional accountants registered in Erzincan Chamber of Independent Accountants and Financial Advisors. The data obtained from the survey was analysed with percentage and frequency descriptive statistics by the help of SPSS program as well as Kruskal-Wallis tests. As a result of the study, professional accountants stated that they made mistakes due to their work intensity. It was also stated that the current auditing system and tax practices are not effective enough to prevent mistakes and fraud in accounting and that a central ethics committee should be established. Finally, it has been determined that there is a significant difference between the experience of professional accountants and their opinions about error, cheating and vocational education in accounting and the errors and frauds they encounter.
\end{abstract}

Keywords: Accounting, Errors, Fraud, Professional Ethics.

Received: 30.04 .2020

Accepted: 26.05 .2020

\section{Suggested Citation:}

Kurnaz, E. ve Karadoğan, S. N., (2020). Investigatin of Errors and Fraud in Accounting in terms of Professional Ethics: Case of Erzincan Province, Journal of Business Academy, 1(2): 125-142.

(C) 2020 Journal of Business Academy. 


\section{GİRIŞ̧}

Muhasebe en kısa tanımıyla iktisadi faaliyetlerde bulunan işletmelerin mali nitelikteki işlemlerini para ile ifade edilmiş şekilde kaydeden, sınıflandıran, özetleyerek rapor eden, sonuçlarını yorumlayan ve analiz eden bir bilimdir. Muhasebe disiplinin gereği olarak işletmelerde yapılan söz konusu mali nitelikteki tüm işlemlerin genel kabul görmüş muhasebe ilkelerine ve kanunlara uygun bir şekilde yapılması gerekmektedir. Ancak işletmelerin sürekli büyümesi, faaliyet alanlarının çeşitlenmesi, birçok iş ve işlemin dijital ortamlarda yürütülmesi, paydaşların beklentilerinin farklılaşması ve çalışan sayısının artması işletmelerde hatalı ve hileli işlemlerin sayısında artışlara neden olabilmektedir.

İşletmelerin başta devlet olmak üzere yatırımcılara, çalışanlara kısacası tüm paydaşlara karşı doğru ve güvenilir bilgi sunma sorumlulukları vardır. Bu sorumlulukta işletme içerisinde yöneticilere yüklenmiştir. Yöneticiler bazen muhasebenin temel kavramlarından biri olan sosyal sorumluluk ilkesinden uzaklaşarak kendi menfaatlerini diğer kesimlerin menfaatlerinin üstünde tutabilmekte ve mali nitelikteki bilgi kullanıcılarını yanıltacak şekilde kararlar verebilmektedir. Ortaya çıkan bu hatalı ve hileli işlemler hem işletmenin imajını menfi yönde etkilemekte hem de yapılacak denetimlerde işletmenin aleyhinde sonuçların ortaya çıkmasına neden olabilmektedir. İşletmelerde meslek etiği dışı davranışlar olarak bilinen hata ve hileye başvurulması aynı zamanda işletmelerin uzun vadede telafisi zor sorunlarla karşılaşmasına da yol açabilmektedir.

Muhasebede yapılan hata ve hilelerin meslek etiği açısından değerlendirilmesi ve muhasebe meslek mensuplarının söz konusu hususlara ilişkin görüşlerinin ortaya konulması bu çalışmanın ana amacını oluşturmaktadır. Bu amaç doğrultusunda Erzincan ilindeki Serbest Muhasebeci Mali Müşavirler Odası'na kayıtlı olan ve aktif bir şekilde çalışan muhasebe meslek mensuplarına bir anket çalışması yapılmıştır. Anketlerden elde edilen veriler SPSS 20.00 programı yardımıyla analiz edilmiştir. Son olarak elde edilen analiz sonuçlarına göre araştırma ile ilgili çeşitli değerlendirilmelerde bulunulmuştur.

\section{KAVRAMSAL ÇERÇEVE}

Hata kavramı literatürde istemeyerek veya bilmeyerek yapılan yanlış, kusur veya yanılma olarak ifade edilmektedir. Bu açıdan bakıldığında, hatalar istenmeden yapılan yanlışlıklar olarak da ifade edilebilir (Yaman, 2008: 145). İşletmelerde yapılan hatalar birçok farklı şekillerde yapılabilmekte veya sinıflandırılabilmektedir. Bunlardan birisi de finansal tablolarda veya muhasebe bilgi sisteminde yapılan hatalardır. Finansal tablolardaki hatalar tutarın ve açıklamanın gözden kaçması gibi kasıt olmaksızın yapılan yanlışlıkları ifade eder. Bu bağlamda, muhasebe ilkeleri uygulanırken sunma veya açıklama, kayda alma, değerleme ve sınıflandırma gibi konularda yapılan yanlışlıklar da hata olarak ifade edilmektedir (Alagöz, 2008: 116). Muhasebe bilgi sisteminde meydana gelen hatalar büyük ölçüde bilgisizlik, dikkatsizlik, ihmal ve irade dışı işlemler sonucu ortaya çıkmaktadır (Dumanoğlu, 2005: 349). Muhasebe mesleğindeki hatalar genel kabul görmüş muhasebe ilkeleri, kanun, yönetmelik ve yönerge gibi yasal mevzuatta yer alan işletme politikalarına ve herkes tarafından kabul edilmiş diğer ilke ve prensiplere uymayan fakat kasıtlı olarak yapılmamış davranışlar olarak da açıklanabilir (Kirik, 2007: 39). Teknolojinin gelişmesi, muhasebe işlemlerinde gerçekleşen hataları büyük oranda azaltmış olsa da uygulamada birtakım hataların yapılabildiği görülmektedir. Bu hatalar; matematiksel hatalar, kayıt hataları, nakil hataları, unutma ve tekrarlama hataları ve bilanço hataları şeklinde sınıflandırılmaktadır (Irmak vd., 2002: 33).

Matematiksel hatalar, fiş girişi sırasında ek olan belgelere ait toplamlarda reeskont, faiz ve karşılık gibi hesaplar nedeniyle muhasebenin dışında yapılan matematiksel işlemlerde meydana gelen hatalar şeklinde açıklanabilir. Kayıt ve nakil hataları, günümüzde muhasebe işlemleri 
önemli ölçüde bilgisayar ortamında yapılmaktadır. Dolayısıyla kullanıcıların muhasebe işlemlerini sisteme taşırken rakamlarda ya da hesaplarda yaptıkları hatalar bu hata türü kapsamında değerlendirilmektedir. Eğer muhasebe işlemleri manuel olarak yürütülüyor ise, herhangi bir kayıtın borç ve alacağının birbirini tutmaması veya yevmiye defterinden defteri kebire nakil olurken başka hesaplara veya yanlış tutarların aktarılması şeklinde de ortaya çıkan hatalardır (Erol, 2008: 231). Unutma ve tekrar kaydetme hataları, işletmelere ait alış, satış ve gider gibi işlemlerin gerçekleştiği döneme kaydedilmemesi veya kayıtlarda hiç yer almaması şeklindeki hatalardır. Tekrarlama diğer bir ifadeyle mükerrer kayıt hataları ise, bir işlemin ilgili defter kayıtlarına birden çok kaydedilmesi şeklinde ortaya çıkan hatlardır. Son olarak değerleme hataları olarak da bilinen bilânço hataları, işletmelerin muhasebe kayıtlarındaki hesaplarının aktif ve pasiflerinde değerleme yapılırken, yıpranma payının veya karşılık ayırmanın muhasebe ilkelerine ve yasalara uygun şekilde hesaplanmamasından kaynaklı hatalardır (Baskan, 2013: 8).

Amerikan Hile İnceleme Birliği (Association of Certified Fraud Examiners, ACFE) hileyi "kişi veya kişilerin çalıştıkları veya iliş̧k halinde bulundukları işletmelerin varlık ya da kaynakların, bilinçli olarak kendi çıkarları için değiştirerek yararlanılması" şeklinde tanımlamıştır (ACFE, 2010: 6). Hile, işletmenin mevcut kaynaklarını ve varlıklarını çalışanların kasıtlı bir şekilde kullanmasıdır. Hilenin temelinde bir grubun veya bir kişinin zararına sebep olacak bir şekilde kendisine fayda sağlamak amacıyla, kasıtlı bir şekilde karşı tarafı kandırma amacı vardır (Bozkurt, 2011: 60). Hile, bir kötülük ya da ağır bir kusur olarak açıklanmaktadır. Aynı zamanda hileyi ifade etmek için "zimmet" veya "güveni kötüye kullanma" terimleri de kullanılmaktadır (Holmes vd., 1975: 133). Muhasebe hileleri ise, işletme sahip veya çalışanları tarafından işletmenin varlıklar ya da kaynaklarının kasıtlı olarak yanlış hesaplarda gösterilmesi, suiistimal edilmesi, yanlış yönlendirilmesi sonucunda doğru ve güvenilir olmayan finansal tabloların hazırlanması şeklinde ortaya çıkan faaliyetlerdir (Kula vd., 2008: 64). İşletme sahip, ortaklar veya çalışanlarının yolsuzlukların üstünü örtmek istemesi, zimmetlerin gizlenmesi daha az vergi ödeme ve kar dağıtma düşüncesi veya hak edilmeyen teşvikleri kullanabilme gibi istekleri muhasebede hile yapılmasının en önemli nedenleri arasında gösterilmektedir (Baskan, 2013: 8). Ayrıca işletmenin karını artırmak ya da azalmak amacı için de muhasebe bilgileri üzerine hile yapılabilmektedir. Örneğin stokları daha az göstermek, yıpranma paylarını yüksek hesaplamak veya gelir tahakkuklarını doğru bir şekilde yapmamak gibi hileli yollarla İşletmenin kârını olduğundan daha az göstermesi mümkündür. Tam tersi yöntemlerle veya benzeri uygulamalar ile işletme karını daha fazla gösterebilir (Kaval, 2005: 65-66).

Bir kişiyi hile yapmaya yönelten birçok unsur bulunmaktadır. Bu unsurlar hile üçgeni olarak da ifade edilmektedir. Hile üçgeninde bulunan temel üç unsur bir araya gelmedikçe hile eylemi ortaya çıkmamaktadır. Cressey önemli bir hile araştırması olup, insanların neden hile yaptıklarını açıklayan hile üçgeni teorisini geliştirmiştir. Bunun sonucunda hileyi oluşturan üç unsur; baskı, fırsat ve kendini haklı gösterme olarak belirlemiştir. Bu unsurlar Şekil 1'de verilmiştir (Bozkurt, 2011: 113).

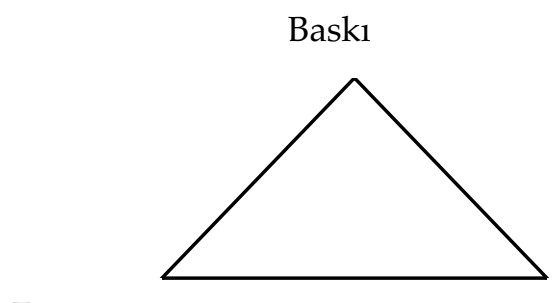

Firsat

$$
\text { Şekil 1: Hile Üçgeni Haklı Gösterme }
$$

Kaynak: Ramos, 2003: 28 
Hileler yapılış şekillerine ve yapıldığı alana göre farklılık göstermektedir. Örneğin muhasebede hile grupları, müşteri hileleri, iş gören hileleri, yönetim hileleri ve satıcı hileleri şeklinde meydana gelebilmektedir (Bozkurt, 2011: 64). Muhasebede gerçekleşen hilelerde amaç menfaat sağlamak olduğu için uygulamada birçok farklı şekilde ortaya çıkabilmektedir. Bunları kasti hatalar, kayıt dışı işlemler, işlemden önce ve sonra kayıt, paravan hesaplar, bilanço hileleri ve bilgisayar hileleri şeklinde sınıflandırmak mümkündür (Çelik, 2010: 27).

Etik kavramı ise, Yunanca "Ethikos" veya "Ethos" sözcüklerinden türemiş ve günümüze kadar gelmiştir. Etik, kişilerin bireysel ve toplumsal ilişkilerinin temelini oluşturan değerleri, kuralların ahlaki tarafını inceleyen ve doğru ile yanlışı, iyi ile kötüyü, haklı ile haksızı ayırt ederken kullanılan ölçütler olarak tanımlanmaktadır (Dinç ve Cengiz, 2014: 223). Meslek etiği, bireyin meslek alanı fark etmeksizin, ahlaki kültürünü, mesleki özelliklerini ve toplumsal sorumluluk kurallarını dikkate alarak uygun biçimde oluşturma şeklidir (Aymankuy ve Sarığlan, 2010: 30). Meslek etiğinin asıl amacı; topluma göre değişiklik arz eden etik kurallar için belirli değerlerin tespit edilmesi ve bu değerlerin uluslararası alanda kabul görmesini sağlamaktır (Akbaş vd., 2009: 175).

Muhasebe mesleğinde etik, muhasebe meslek mensuplarının iş dünyasındaki ilişkilerini kanunlara uygun olarak düzenleyen ve güvenilir bilgileri taraflara sunmayı amaçlayan kurallar bütünüdür (Azaltun ve Kaya, 2006: 107). Bu doğrultuda muhasebe meslek mensuplarının insanlara karşı olan sorumlulukları üzerinde duran meslek etik kurallarının üç özelliği öne çıkmaktadır. Bunlar (TESMER, 2010: 235);

- Bağımsız, dürüst ve tarafsız olma,

- Mesleğin gerektirdiği teknik bilgi, deneyim ve yeterliliğe sahip olma ve

- Mükelleflerine hizmet sunarken mesleki özen ve titizliği gösterme ve sorumlulukların bilincinde olmalı şeklide sıralanabilir.

Muhasebe meslek mensuplarının, topluma, müşterilere, devlete ve kendilerine karşı sorumlulukları vardır. Muhasebede etik ile ilgili oluşturulan düzenlemeler de bu tür sorumlulukları göz önünde bulundurularak yapılmakta ve uygulamaya konulmaktadır. Bu anlamda, Dünya'da olduğu gibi Türkiye'de de muhasebe meslek etiği ve meslek mensuplarının uyması gereken etik değerlerle ilgili yapılan düzenlemeler ve çalışmalar bulunmaktadır (Tükenmez ve Kutay, 1998: 442).

Muhasebe meslek etiği denince akla ilk gelen uluslararası kuruluşların başında Uluslararası Muhasebeciler Federasyonu (nternational Federation of Accountants - IFAC) ve Amerikan Ruhsatlı Kamu Muhasebecileri Enstitüsü (American Institue of Certified Public Accountants AICPA) gibi kuruluşlar gelmektedir. IFAC, tüm dünyada muhasebe meslek mensuplarının uygulayacağı, kamu menfaatine yönelik etik standartlarının oluşturulmasını hedefleyen Uluslararası Etik Standartları Kurulu'nu kurmuş ve mesleki standartlaşmayı sağlamak için “Dürüstlük, Nesnellik, Mesleki Yeterlilik-Gerekli Özen, Gizlilik ve Mesleki Davranış” olmak üzere beş temel ilke belirlemiştir (Özçelik ve Keskin, 2017: 141). Türkiye' de ise, muhasebe meslek etiğiyle ilgili IFAC'ın çalışmaları dikkate alınarak 1990 yılında çalışmalara başlanmıştır. Yapılan çalışmalar sonucunda "Profesyonel Muhasebeciler İçin Meslek Ahlakı Kuralları" adlı bir yönerge yayınlanmıştır. Daha sonra 3568 sayılı yasa ile 2007yılında "Serbest Muhasebeciler, Serbest Muhasebeci Mali Müşavirler ve Yeminli Mali Müşavirlerin Mesleki Faaliyetlerinde Uyacakları Etik İlkeler Hakkında Yönetmelik" Resmi Gazetede yayımlanmıştır (TÜRMOB, 2007). Ayrıca Meslek ahlakını koruma görevi Türkiye Serbest Muhasebeci Mali Müşavirler ve Yeminli Mali Müşavirler Odaları Birliği (TÜRMOB)'ne verilmiştir. Meslek mensuplarının uyması gereken kurallar geliştirilirken, İngiltere ve Galler Yeminli Muhasebeciler Enstitüsü tarafından 
yayınlanan "Meslek Etik Rehberi " esas alınmıştır. Rehberde meslek mensuplarının uyması gereken kurallar "dürüstlük, tarafsızlık, mesleki bilgi ve donanım, mesleki özen, nazik ve anlayışlı olmak" olarak açıklanmıştır (Sözbilir, 2000: 63).

Muhasebeciler İçin Uluslararası Etik Standartları Kurulu (IESBA)'nu geliştirdiği ve Kamu Gözetim Kurumu (KGK)'nun da benimsediği “Bağımsız Denetçiler İçin Etik Kurallar Standardının (Bağımsızlık Standartları Dâhil)" yeni sürümü 22/09/2019 tarihli ve 30896 sayılı Resmî Gazete' de yayımlanmıştır. Yeni sürüme göre:

- "Kavramsal çerçevenin genişletilmesi,

- Alinacak önlemlerin revizyonu,

- Teşvik projesinin hayata geçirilmesi,

- Azami denetlenebilir döneme ve ara verme süresine ilişkin daha kapsaml hükümler,

- Daha güçlü bağımsızlık hükümleri,

- Mesleki muhakemede bulunurken durum ve gerçekleri anlamadaki önemi vurgulamak için yeni rehberlik sağlanması,

- Temel ilkelere uyumun, bir denetimde veya diğer güvence denetimlerinde mesleki şüpheciliğin uygulanmasını nasıl desteklediğini açıklayan yeni rehberlik sağlanması" gibi hükümler getirilmiştir (www.kgk.gov.tr).

Muhasebe meslek mensuplarının toplumda oluşturduğu güven ve itibarlarının artırılabilmesi için yeterli mesleki bilgi ve beceri ile birlikte mesleki etik kuralları çerçevesinde hareket etmeleri beklenmektedir (Kutluk ve Ersoy, 2011: 425). Muhasebe mesleğine karşı oluşan güvenin korunabilmesi ve mesleğe olan ilginin artırılabilmesi, meslek mensuplarının etik kurallara uygun davranmaları sonucunda gerçekleşecektir (Sakarya ve Kara, 2010: 58). Muhasebe meslek mensupları için oluşturulmuş mesleki etik kurallarının meslek mensupları tarafından uygulanması beklenir. Belirlenen bu etik kurallara uymayanlar gerekli yaptırımlarla karşı karşıya kalırlar. Bu yaptırımlar, muhasebe mesleğinin toplumdaki itibarının gelişmesine katkı sağlayacaktır (Selimoğlu, 1997: 146). Ancak bu alanda yapılan tüm çalışmalara rağmen çeşitli nedenlerden dolayı meslek etiği dışı davranışlar sergileyebilen meslek mensuplarının olduğunu söylemek mümkündür. Muhasebe mesleğinde yapılan etik olmayan davranışlar; belgeleri yok etmek, yok edilen belgelerin yerine başka belgeleri yerleştirmek, defter, hesap kayıtlarında kasıtlı olarak hata yapmak, gerçek olmayan kişiler adına işlemler yapmak şeklinde sıralanabilir (Dinç ve Cengiz, 2014: 212).

Muhasebe bilgi siteminin ürettiği bilgilerden faydalanan birçok taraf vardır. Bunlardan en önemlilerinden birisi de devlettir. Bu durum muhasebede sosyal sorumluluğun önemini daha da artırmaktadır. Muhasebe meslek mensuplarının böyle geniş bir yelpazeye hizmet sunuyor olması yaptıkları işin sonucundan birçok kesimin etkileneceğini göstermektedir. Dolayısıyla meslek mensuplarının hata, hile ve meslek etiğine karşı nasıl bir tutum içinde olduklarının belirlenmesi büyük önem taşımaktadır (Karabayır vd., 2018: 334).

\section{LITERATÜR İNCELEMESI}

Literatürde muhasebede gerçekleştirilen hata ve hilelerin meslek etiği açısından incelenmesiyle ilgili birçok çalışmanın yapıldığı görülmektedir. Bu konuda yapılmış teorik ve uygulamalı çalışmalardan bazıları aşağıda sunulmuştur

Bayraktar (2019) çalışmasında, muhasebede yapılan hata ve hilelerin, muhasebe bilgi sistemine etkilerini ve meslek mensuplarının hata ve hilelere karşı tutumlarını belirlemek için Sivas ilinde 
bulunan meslek mensupları üzerine ankete dayalı bir araştırma gerçekleştirilmiştir. Araştırmada, kişiyi hile yapmaya yönelten kabul görmüş 'hile üçgeninin' tek başına yetersiz bir teori olduğu sonucuna varılmıştır. Kişileri hileye yönelten etkenler; başta özgüven etkeni olmak kaydıyla baskı, fırsat, rekabet, adaletsizlik, denetim yetersizliği ve son olarak kendini haklı görme etkeni olarak gösterilmiştir.

Aktekin (2019) çalışmasında muhasebe denetiminde karşılaşılan hilelerin nedenlerini ortaya koymak ve meslek mensuplarının bu tür durumlar karşısındaki tutumlarını belirlemeyi amaçlamıştır. Bu doğrultuda Elazığ ve Bingöl illerindeki SMMM'lere ve stajyerler bir anket uygulamıştır. Araştırma sonucunda katılımcıların tutumları arasında anlamlı bir farklılığın olmadığı tespit edilmiştir.

Ahinful vd. (2017) çalışmalarında meslek etiğinin muhasebe meslek mensupları ile ilişkili olup olmadığını belirlemek ve muhasebede hileye neden olan faktörleri tespit etmeyi amaçlamışlardır. $\mathrm{Bu}$ kapsamda Gana'nın doğu bölgesindeki muhasebe meslek mensuplarına bir anket uygulanmıştır. Araştırma sonucunda meslek etiğinin muhasebe meslek mensuplarını ilgilendirdiğini ancak, etik ilkelere uymada zorluklarla karşılaşıldığı tespit edilmiştir. Bu nedenle muhasebe mesleğinde tüm tarafların etik bilgilerinin artırılmasını sağlayacak davranışlarda bulunması gerektiği yönünde değerlendirmelerde bulunulmuştur.

Korucu (2017) çalışmasında, muhasebe meslek mensuplarının hata ve hile yapma sebeplerini ve etik konusunu ele almıştır. Bu doğrultuda ilk olarak hata ve hile konuları ele alınmış daha sonra etik konusu üzerinde durulmuştur. Teorik olan durumu uygulamada görmek amaciyla bir de anket düzenlenmiştir. Araştırma sonucunda meslek mensuplarının deneyimlerinin ve eğitim düzeylerinin hata ve hile yapmada etkili olduğu tespit edilmiştir.

Özçelik vd. (2017) çalışmalarında, muhasebe meslek mensuplarının muhasebede hata ve hile algılarını tespit etmek amacıyla Batı Akdeniz Bölgesinde faaliyet gösteren muhasebe meslek mensuplarına anket uygulamıştır. Çalışma sonucunda, muhasebe hatalarının bulunabilmesi için denetim faaliyetlerinin etkin olmadığı tespit edilmiştir. Bağımsız denetim veya iç denetim gibi çeşitli denetim otoritelerinin faaliyetlerini sıklaştırmaları gerektiği ifade edilmiştir. Oluşturulan hipotezlere göre, katılımcıların, muhasebede yapılan hata ve hilelerle ilgili ifadelere katılma düzeyleri ile cinsiyet, yaş, öğrenim durumu, unvan ve mesleki deneyim değişkenleri arasında anlamlı bir farklılığın olmadığı tespit edilmiştir.

Aslan vd. (2017) çalışmalarında, muhasebede meydana gelen hata ve hileler arasındaki farklar üzerinde durmuş, Türkiye'de ve Dünya'da gerçekleşen olumsuz sonuçları ortaya çıkarmayı amaçlamışlardır. Bu kapsamda Yalova ilindeki muhasebe meslek mensuplarına anket yapılmıştır. Anket sonuçlarına göre, katılımcılar mesleki standartlara uygun olarak işlerin yürütülmediğini, meslek ahlakına uymayan kişilere verilen cezaların yeterli olmadığını ve Türkiye'de bu kapsamda yapılan düzenleme ve çalışmaların eksik olduğunu ifade etmişlerdir. Ayrıca vergi uygulamaları ve vergi oranlarının da muhasebede yapılan hata ve hileler üzerinde etkili olduğu yönünde düşüncelerini belirtmişlerdir.

Gümüş ve Göğebakan (2016) muhasebe mesleği ve meslek mensuplarının etiğe karşı tutumları ile muhasebede meydana gelen hile ve hata konuları ele almışlardır. Bu kapsamda Aydın'da bulunan muhasebe meslek mensuplarının eğitim düzeyleri, tecrübe ve deneyimleri, meslek etiği açısından meslekteki hile ve hatalarla ilgili bir ankete dayalı bir araştırma yapılmıştır. Araştırma sonucunda, muhasebe meslek mensuplarının meslekte gerçekleştirdikleri hile, hata ve meslek etiğinde eğitim düzeyleri, tecrübe ve deneyimlerinin etkili olduğu ortaya çıkmıştır.

Bayraktaroğlu (2016) çalışmasında, muhasebede etik dışı davranışları önlemede iç denetiminin katkısını ortaya koymayı amaçlamıştır. Bu bağlamda Antalya, Burdur, Isparta' da faaliyette 
bulunan muhasebe iç denetim sistemine sahip 87 işletme incelenmiştir. Anket yöntemi ve yüz yüze görüşmeler yapılarak elde edilen veriler analiz edilmiştir. Yapılan analizler sonucunda etkin bir iç denetim ve iç kontrol sistemi sayesinde işletmelerde meydana gelebilecek hatalı veya hileli diğer bir ifadeyle, meslek etiği dışı davranışların azaltılmasına önemli derecede katlı sağlayacağı ifade edilmiştir.

Okay (2016) muhasebe meslek mensuplarının meslek etiğine karşı tutumları, muhasebede gerçekleştirilen hata ve hilelerin neler olduğu ve etik dişı davranışa yönelten faktörleri belirlemeye yönelik bir çalışma yapmıştır. Bu doğrultuda Diyarbakır'da bulunan muhasebe meslek mensuplarına bir anket uygulanmıştır. Çalışma sonucunda, etik dişı davranışlar yapmaya yönelten faktörlerin başında "devletin adil bir vergi sisteminin olmaması" belirtilmiştir. Araştırmada devletin tüm kesimler tarafından kabul görebilecek bir vergi reformuna gitmesi şikâyetleri azaltacağı ve meslek mensuplarını etik dışı davranışlarla karşı karşıya kalmalarını önleyeceği şeklinde değerlendirmelerde bulunulmuştur.

Aytekin vd. (2015) çalışmalarında, Balıkesir ilinde bulunan muhasebe meslek mensuplarının muhasebede hata ve hile olgularına katılma ve müşterileri açısından hile belirteçleri ile karşılaşma düzeylerini belirlemeyi amaçlamışlarıdır. Araştırma neticesinde kadın katılımcıların hile belirteçlerine daha çok rastladıkları, eğitim düzeyinin artması ve unvanının da değişmesi ile birlikte hata ve hileyle ilgili olgulara katılma derecesinde farklılıklar oluştuğu gözlemlenmiştir.

Güney ve Çınar (2012) çalışmalarında, muhasebe meslek mensuplarının meslek etiğine karşı gösterdikleri tutumu ele almıştır. Bu doğrultuda Erzurum ilinde bulunan muhasebe meslek mensuplarına anket uygulanmıştır. Araştırmada meslek mensupları meslek etik ilkelerinin çok önemli olduğunu ve bu ilkelere aykırı bir şekilde davranılmasına karşı olduklarını fakat uygulama kısmında etik dışı davranışlar ile mutlaka karşılaşıldığını ve etik konusunda daha fazla eğitim desteği talep ettikleri sonucuna varılmıştır. Ayrıca eğitim ve gelir düzeyi ile etik ilkelere karşı oluşan bağlılık arasında paralel bir ilişkinin olduğu tespit edilmiştir.

Kirkos vd. (2007) çalışmalarında hileli finansal tablolar yayımlayan firmaları tespit etmede veri madenciliği sınıflandırma tekniklerinin etkinliğini araştırmayı amaçlamışlardır. Araştırmada veri madenciliği tekniklerinin yapılan hileleri ortaya çıkarmada denetçilere kolaylıklar sağlayabileceği ifade edilmiştir. Son olarak hileli finansal tabloları belirlemede kullanılan bazı yöntemler karşılaştırılmıştır.

Bierstaker vd. (2006) çalışmalarında muhasebecilerin, iç denetçilerin ve sertifikalı hile denetçilerinin hileleri önleme ve tespit etme yöntemlerini ne ölçüde kullandıkları ve bu yöntemlerin etkinliği ile ilgili algılarını belirlemeyi amaçlamışlardır. Bu kapsamda katılımcılara bir anket uygulanmıştır. Araştırma sonucunda, hile tespitinde keşif örneklemesi ve veri madenciliği gibi yöntemlerin etkili olmasına rağmen kaynaklar yetersiz olduğu için kullanılamadığı ifade edilmiştir. Ayrıca hile tespit yöntemleriyle ilgili kararlar alırken fayda maliyet dengesinin gözetildiği yönünde değerlendirmelerde bulunulmuştur.

Her alanda olduğu gibi muhasebe alanında da hata, hile ve meslek etiği dışı davranışların önüne geçmek ve hesap verebilirliği, şeffaflığı, sorumluluk bilincini artırabilmek için çeşitli düzenlemeler ve uygulamalar yapılmaktadır. Söz konusu çalışma ile tüm bu düzenlemelere rağmen muhasebe meslek mensuplarının hata hile ve etik dışı davranışlarla karşılaşıp

karşılaşmadıkları yönünde bir durum tespitinin yapılarak literatüre katkı sağlaması beklenmektedir.

\section{METODOLOJi}

Çalışmanın bu kısmında araştırmanın amacı, kapsamı ve yöntemi, güvenilirlik analizi ve elde edilen bulguların değerlendirilmesi sırasıyla ele alınacaktır. 


\subsection{Araştırmanın Amacı}

$\mathrm{Bu}$ çalışmada temel amaç, muhasebede yapılan hata ve hileleri meslek etiği açısından değerlendirmek ve muhasebe meslek mensuplarının söz konusu hususlara ilişkin görüşlerini ortaya koymaktır. Ayrıca muhasebede hata ve hilelerin nedenlerini ve muhasebe meslek mensuplarını hata ve hile yapmaya yönelten etkenlerin neler olduğunu belirlemek çalışmanın bir diğer amacını oluşturmaktadır.

\subsection{Araştırmanın Kapsamı ve Yöntemi}

Çalışmanın ana kütlesini Erzincan'daki Serbest Muhasebeci Mali Müşavirler Odası'na kayıtlı olan ve aktif bir şekilde çalışan muhasebe meslek mensupları oluşturmaktadır. Bu kapsamda söz konusu odada 98 muhasebe meslek mensubu bulunmaktadır (https://erzincansmmmo.org.tr/uye-listesi/). Örneklem seçimi yapılmayıp, ana kütlenin tamamına ulaşılması hedeflenmiştir.

Çalışmanın amacı doğrultusunda hazırlanan anket oluşturulurken, literatürdeki çalışmalardan, muhasebe meslek mensupları ile yapılan görüşmelerden ve Okay (2011)'ın çalışmasından yararlanılmıştır. İki bölümden oluşan anket formunun birinci bölümde katılımcıların demografik özelliklerini belirlemeye yönelik sorular; ikinci bölümde ise, muhasebede yapılan hata, hile ve meslek etiğiyle ilgili muhasebe meslek mensuplarının düşüncelerini belirlemeye yönelik sorular yer almaktadır.

Verilerin toplanmasında kullanılan anket forumları katılımcılara yüz yüze uygulanmıştır. Araştırmanın ana kütlesini oluşturan 98 kişinin $67^{\prime}$ sinden geçerli geri dönüş alınabilmiştir. Bu oran hedef kitlenin \%68'ine ulaşıldığını göstermektedir.

Elde edilen veriler, SPSS 20.00 programı yardımıyla frekans ve yüzde gibi tanımlayıcı istatistiklerin yanı sıra Kruskal-Wallis Testi ile analiz edilmiştir.

\subsection{Güvenilirlik Analizi}

Cronbach's Alfa katsayısının 0-1 arasında değiştiği, değerlendirme kriterlerine göre “ $0.00<0.40$ ise ölçek güvenilir değil, $0.40<0.60$ ise ölçek düşük güvenirlikte, $0.60<0.80$ ise ölçek oldukça güvenilir ve $0.80<1.00$ ise ölçek yüksek derecede güvenilir bir ölçek" olarak değerlendirildiği ifade edilmektedir (Tavşancıl, 2005: 144). Bu kapsamda çalışmada kullanılan ölçeğin Cronbach's Alfa değeri 0,692 olarak hesaplanmıştır. Bu değer ölçeğin oldukça güvenilir olduğunu göstermektedir.

\section{ARAŞTIRMA BULGULARININ DEĞERLENDİRİLMESİ}

Araştırmanın bu kısmında, muhasebe meslek mensuplarına ait demografik bilgiler ve muhasebe meslek mensuplarının muhasebede hata, hile ve meslek etiğine yönelik tutumlarına ilişkin bulguların değerlendirilmesi yapılmaktadır. Söz konusu hususlar aşağıda tablolar yardımıyla sırasıyla açıklanmaktadır.

Araştırmaya katılan muhasebe meslek mensuplarının demografik özelliklerine ilişkin bilgiler Tablo 1'de sunulmuştur.

Tablo 1. Demografik Özelliklere İlişkin Bulgular

\begin{tabular}{lccc}
\hline & Demografik özellikler & $\mathbf{N}$ & $\mathbf{\%}$ \\
\hline \multirow{2}{*}{ Cinsiyet } & Kadın & 7 & 10,4 \\
\cline { 2 - 4 } & Erkek & 60 & 89,6 \\
\hline
\end{tabular}


E. Kurnaz - S. N. Karadoğan, 1 (2):125-142

\begin{tabular}{|c|c|c|c|}
\hline \multirow{3}{*}{ Yaş } & 30 ve alt1 & 7 & 10,4 \\
\hline & $31-39$ & 16 & 23,9 \\
\hline & 40 ve üstü & 44 & 65,7 \\
\hline \multirow[t]{3}{*}{ Eğitim durumu } & Lise & 6 & 9 \\
\hline & Lisans & 57 & 85,1 \\
\hline & Lisansüstü & 4 & 6 \\
\hline \multirow[t]{2}{*}{ Mesleki unvan } & SM & 5 & 7,5 \\
\hline & SMMM & 62 & 92,5 \\
\hline \multirow[t]{3}{*}{ Mesleki tecrübe } & 10 yıldan az & 14 & 20,9 \\
\hline & $11-20 \mathrm{yll}$ & 22 & 32,8 \\
\hline & 21 yıldan fazla & 31 & 46,3 \\
\hline \multirow[t]{3}{*}{ Çalıştırdığınız eleman sayısı } & Yalnızım & 19 & 28,4 \\
\hline & $1-5$ kişi & 47 & 70,1 \\
\hline & 6 ve üstü & 1 & 1,5 \\
\hline \multirow[t]{5}{*}{ Müşteri sayınız } & 25 ve alt1 & 10 & 14,9 \\
\hline & $26-35$ & 8 & 11,9 \\
\hline & $36-45$ & 9 & 13,4 \\
\hline & $46-55$ & 17 & 25,4 \\
\hline & 56 ve üstü & 23 & 34,3 \\
\hline \multirow[t]{5}{*}{ Müşteri kitlenizin şirket türleri nelerdir? } & Tek şahıs işletmeleri & 11 & 16,4 \\
\hline & Kollektif şirketler & 2 & 3 \\
\hline & Kooperatifler & 1 & 1,5 \\
\hline & Limited şirketler & 48 & 71,6 \\
\hline & Anonim şirketler & 5 & 7,5 \\
\hline
\end{tabular}

Tablo 1'de katılımcıların demografik özelliklerinden öne çıan yüzdelere bakıldığında; ankete katılan 67 kişinin \%89,6'sının erkek, \%65,7'sinin 44 ve üstü yaş aralığında, \%85,1'inin lisans mezunu, \%92,5'inin SMMM, \%46,3'ünün mesleki tecrübesinin 21 y1ldan fazla, \%70,1'inin çalıştırdığı eleman sayısının 1-5 kişi arasında, \%34,3'ünün müşteri sayısının 56 ve üstü, \%71,6'sının müşteri kitlesinin limited şirketlerden oluştuğu görülmektedir.

Tablo 2. Muhasebede Yapılan Hata ve Hilelerin En Önemli Nedenlerine İlişkin Bulgular

\begin{tabular}{|c|c|c|c|}
\hline & & $\mathbf{N}$ & $\%$ \\
\hline \multirow{5}{*}{$\begin{array}{l}\text { "Muhasebede yapilan hataların nedenleri } \\
\text { sizce nelerdir?" }\end{array}$} & Bilgisizlik & - & - \\
\hline & Dikkatsizlik & 21 & 31,3 \\
\hline & Özen göstermemek & 4 & 6 \\
\hline & Tecrübesizlik & 1 & 1,5 \\
\hline & İş yoğunluğu & 41 & 61,2 \\
\hline \multirow{4}{*}{$\begin{array}{l}\text { “Bilançoda işletmenin aktif hesaplarının } \\
\text { olduğundan daha iyi gösterilmesinin en } \\
\text { büyük nedeni sizce hangisidir?” }\end{array}$} & $\begin{array}{l}\text { Kredi kuruluşlarından daha } \\
\text { fazla kredi almak }\end{array}$ & 37 & 55,2 \\
\hline & Hisselerinin fiyatını arttırmak & 1 & 1,5 \\
\hline & $\begin{array}{l}\text { İşletmenin imajını } \\
\text { kuvvetlendirmek }\end{array}$ & 27 & 40,3 \\
\hline & Vergi ödeme arzusu & 2 & 3 \\
\hline
\end{tabular}

Tablo 2' deki bulgulara bakıldığında; katılımcıların \%61,2'si muhasebede yapılan hataların nedeni olarak iş yoğunluklarını öne çıardıkları görülmektedir. Ayrıca meslek mensuplarının $\% 55,2$ 'sinin bilançoda işletmenin aktif hesaplarının olduğundan daha iyi gösterilmesinin en 
büyük nedeni olarak, kredi kuruluşlarından daha fazla kredi almak amacıyla yapıldığı ifade etmiştir.

$\mathrm{Bu}$ doğrultuda literatürde benzer ölçeğin kullanıldığı çalışmalarda elde edilen bulgulara bakıldığında, Aktekin (2019) çalışmasında muhasebede yapılan hataların daha çok iş yoğunluğundan ileri geldiği yönünde, yani bu çalışmada elde edilen sonuç ile benzerlik gösteren bir sonuç elde etmiştir. Okay (2011) ise, yapılan hataların nedeninin bilgisizlik ve özen göstermemekten kaynaklandığın ifade etmiştir. Ayrıca aktif hesapların olduğundan daha iyi gösterilmesinin nedeni olarak her iki çalışmada kredi kuruluşlarından daha fazla kredi almak isteğinin olduğu ifade edilmiştir. Dolayısıyla bu çalışmada elde edilen bulgular, ilgili çalışmaların sonuçlarıyla benzerlik göstermektedir. Muhasebe meslek mensuplarının sundukları hizmetlerin önemli bir kısmı dijital ortamlara taşınmasına rağmen iş yoğunluğunun yapılan hatalar üzerinde etkisinin devam ettiği görülmektedir. Ayrıca son yıllarda yaşanan ekonomik sıkıntılar işletmelerde kaynak sıkıntısına neden olmakta ve işletmeleri kredi kuruluşlarına yönlendirebilmektedir. Bu durumda işletmeleri farklı beklentiler içerisine sokabilmektedir.

Tablo 3. Muhasebe Meslek Mensuplarının Muhasebe Hata, Hile ve Meslek Etiği Hakkındaki Bakış Açılarına İlişkin Bulgular

\begin{tabular}{|c|c|c|c|c|c|c|c|c|c|c|}
\hline \multirow[t]{2}{*}{ İfadeler } & \multicolumn{2}{|c|}{ 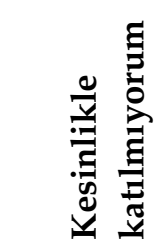 } & \multicolumn{2}{|c|}{ 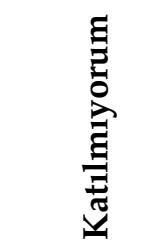 } & \multicolumn{2}{|c|}{ 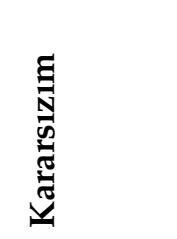 } & \multicolumn{2}{|c|}{ 胥 } & \multicolumn{2}{|c|}{ 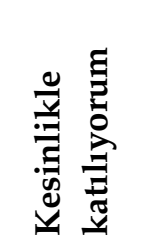 } \\
\hline & $\mathbf{N}$ & $\%$ & $\mathbf{N}$ & $\%$ & $\mathbf{N}$ & $\%$ & $\mathbf{N}$ & $\%$ & $\mathbf{N}$ & $\%$ \\
\hline $\begin{array}{l}\text { "İşimi yaparken meslek ahlak } \\
\text { kuralları çerçevesinde hareket } \\
\text { ediyorum." }\end{array}$ & 2 & 3 & 1 & 1,5 & - & - & 18 & 26,9 & 46 & 68,7 \\
\hline $\begin{array}{l}\text { "Meslek hayatımda bazen teknik } \\
\text { olarak veya mesleki standartlara } \\
\text { uymayacak bir şekilde hareket } \\
\text { etmişimdir." }\end{array}$ & 19 & 28,4 & 21 & 31,3 & 5 & 7,5 & 14 & 20,9 & 8 & 11,9 \\
\hline $\begin{array}{l}\text { "Meslek mensuplarından meslek } \\
\text { ahlakına uymayan davranış veya } \\
\text { işlem yapanlara verilen cezalar } \\
\text { yeterlidir." }\end{array}$ & 16 & 23,9 & 16 & 23,9 & 17 & 25,4 & 7 & 10,4 & 11 & 16,4 \\
\hline $\begin{array}{l}\text { "Meslek ahlakı çerçevesinde yasal } \\
\text { çalışmalar yeterlidir." }\end{array}$ & 15 & 22,4 & 22 & 32,8 & 15 & 22,4 & 11 & 16,4 & 4 & 6 \\
\hline $\begin{array}{l}\text { "Merkezi olarak bir mesleki etik } \\
\text { kurulunun kurulması gerekir." }\end{array}$ & 3 & 4,5 & 4 & 6 & 9 & 13,4 & 20 & 29,9 & 31 & 46,3 \\
\hline $\begin{array}{l}\text { "Mevcut vergi uygulamaları ve } \\
\text { oranları yapılan hata ve hileler } \\
\text { üzerinde etkilidir." }\end{array}$ & 3 & 4,5 & 16 & 23,9 & 11 & 16,4 & 16 & 23,9 & 21 & 31,3 \\
\hline $\begin{array}{l}\text { "Mevcut denetim sistemi } \\
\text { muhasebede hata ve hileleri ortaya } \\
\text { çıarmada yeterlidir." }\end{array}$ & 9 & 13,4 & 18 & 26,9 & 11 & 16,4 & 23 & 34,3 & 6 & 9 \\
\hline
\end{tabular}

Tablo 3'te muhasebe meslek mensuplarının muhasebede hata, hile ve meslek etiğine yönelik bakış açılarına ilişkin bilgiler yer almaktadır. Söz konusu bulgular incelendiğinde; katılımcıların $\% 95,6$ 'sı işlerini yaparken meslek ahlak kurallarına uygun hareket ettiklerini, \%76,2'si merkezi 
olarak bir mesleki etik kurulunun kurulması gerektiğini, \%55,2'si mevcut vergi uygulamaları ve oranlarının yapılan hata ve hileler üzerinde etkili olduğunu ve $\% 43,3$ '̈u de mevcut denetim sisteminin muhasebede hata ve hileyi ortaya çıkarmada yeterli olduğunu ifade etmişlerdir. Bu sonuçların yanı sıra çalışmadan elde edilen diğer bulgular; katılımcıların \%59,7'si meslek hayatları boyunca teknik olarak veya mesleki standartlara uymayacak şekilde hareket etmediklerini, \%47,8'i meslek ahlakına uymayan davranış veya işlem yapanlara verilen cezaların düşük olduğunu ve \%55,2'si meslek ahlakı çerçevesinde yasal çalışmaların yeterli olmadığını ifade etmişlerdir.

Bu sonuçlar Aktekin (2019) ve Okay (2011)'ın çalışmasında kullandığı benzer ölçekle elde ettiği sonuçlarla önemli ölçüde paralellik göstermektedir. Burada ifade edilmesi gereken en önemli konulardan birisi vergidir. Meslek mensuplarıyla yapılan yüz yüze görüşmelerde ve literatürde vergi uygulamalarını konu edinen çalışmalarda işletmelerin vergi oranlarını ve sayısını çok yüksek buldukları ifade edilmektedir. Bu durumunda özellikle muhasebe hileleri üzerinde etkili olduğu söylenebilir. Diğer bir husus meslek etiği dışı davranışlar karşısında cezai yaptırımlar ne kadar yüksek olursa olsun veya denetim faaliyetleri ne kadar etkin olursa olsun ahlaki değerler zayıf olduğu sürece meslek ahlakına uymayan davranışların önüne geçilmesi zor olabilir.

Tablo 4. Muhasebe Meslek Mensuplarının Muhasebe Hata ve Hilelerine Yönelik Sorulan Sorulara Verdikleri Yanıtlara İlişkin Bulgular

\begin{tabular}{|c|c|c|c|}
\hline \multicolumn{2}{|l|}{ İfadeler } & $\mathbf{N}$ & $\%$ \\
\hline \multirow{2}{*}{$\begin{array}{l}\text { "Hesapların tutarını ve sonuçlarını gösteren mizanın bilançoya } \\
\text { çevrilmesi sırasında, hesap sonuçlarının yanlış anlaşılması şeklinde } \\
\text { bilançoda düzensizliğe yol açacak bir hata yaptığınız oldu mu?" }\end{array}$} & Evet & 2 & 3 \\
\hline & Hayır & 65 & 97 \\
\hline \multirow{2}{*}{$\begin{array}{l}\text { "İşletmelerin alacak ve borçlarının veya geçici aktif ve pasif } \\
\text { hesaplarının birbirinden çıkarılması sonucu bazı hesapların } \\
\text { bilançoda noksan olması şeklinde bir hata yaptığınız oldu mu?" }\end{array}$} & Evet & 3 & 4,5 \\
\hline & Hayır & 64 & 95,5 \\
\hline \multirow{2}{*}{$\begin{array}{l}\text { "Herhangi bir işlemin yevmiye defterlerinde tam ve doğru } \\
\text { gösterilmesine rağmen büyük deftere aktarımı sırasında hesap ismi } \\
\text { benzerliği veya başka nedenlerden ötürü yanlış hesaba kayıt } \\
\text { yaptığınız oldu mu?" }\end{array}$} & Evet & 14 & 20,9 \\
\hline & Hayır & 53 & 79,1 \\
\hline \multirow{2}{*}{$\begin{array}{l}\text { "Mesleki hizmet konusunda çalışanlarınızın mesleki tecrübeye ve } \\
\text { bilgiye sahip olmadıkları için müşteriler lehine hatalı işlemler } \\
\text { gerçekleştirdikleri oldu mu?" }\end{array}$} & Evet & 14 & 20,9 \\
\hline & Hayır & 53 & 79,1 \\
\hline \multirow{2}{*}{$\begin{array}{l}\text { "Müşterilerinizin muhasebe bilgilerini zamanında } \\
\text { göndermemesinden kaynaklanan hatalı işlem yaptığınız oldu mu?" }\end{array}$} & Evet & 33 & 49,3 \\
\hline & Hayır & 34 & 50,7 \\
\hline \multirow{2}{*}{$\begin{array}{l}\text { "Dikkatsizlik sonucu borç ve alacak hesaplarını karıştırarak hatalı } \\
\text { bir işlem yaptığınız oldu mu?" }\end{array}$} & Evet & 10 & 14,9 \\
\hline & Hayır & 57 & 85,1 \\
\hline \multirow{2}{*}{$\begin{array}{l}\text { "Bilançoda işletmenin aktif hesaplarının daha iyi veya kötü } \\
\text { gösterilmesini isteyen müşteriniz oldu mu?" }\end{array}$} & Evet & 32 & 47,8 \\
\hline & Hayır & 35 & 52,2 \\
\hline \multirow{2}{*}{$\begin{array}{l}\text { "Benzer hesapların yanlış yerde kullanılmasından ötürü yanlış } \\
\text { raporlama yapılmasını sağladığınız oldu mu?" }\end{array}$} & Evet & 7 & 10,4 \\
\hline & Hayır & 60 & 89,6 \\
\hline \multirow{2}{*}{$\begin{array}{l}\text { “Gelecek yıla ait gelir ve giderlerin içinde bulunulan döneme } \\
\text { kaydedilmesini isteyen müşteriniz oldu mu?" }\end{array}$} & Evet & 12 & 17,9 \\
\hline & Hayır & 55 & 82,1 \\
\hline \multirow{2}{*}{$\begin{array}{l}\text { “Gelir ve giderlerdeki tahakkuk etme esasının yanlış kullanılması } \\
\text { sonucu bilanço karını yüksek veya düşük gösterilmesini isteyen } \\
\text { müşteriniz oldu mu?" }\end{array}$} & Evet & 17 & 25,4 \\
\hline & Hayır & 50 & 74,6 \\
\hline \multirow{2}{*}{$\begin{array}{l}\text { “Uzmanlığınızın bulunmadığı bir alanda uzmanmış gibi } \\
\text { davranarak müşteri kazandığınız oldu mu?” }\end{array}$} & Evet & 5 & 7,5 \\
\hline & Hayır & 62 & 92,5 \\
\hline
\end{tabular}




\begin{tabular}{llll}
\hline "Finansal tabloların gerçekliğini etkilemeyecek düzeyde sayısal & Evet & 32 & 47,8 \\
\cline { 2 - 4 } hata veya işlem yapmışımdır." & Hayır & 35 & 52,2 \\
\hline
\end{tabular}

Tablo 4'te muhasebe meslek mensuplarının muhasebe hata ve hilelerine yönelik sorulan sorulara verdikleri yanıtlara ilişkin bulgular yer almaktadır. Söz konusu bulgular incelendiğinde; katılımcıların \%97'si hesapların tutarını ve sonuçlarını gösteren mizanın bilançoya çevrilmesi sırasında, hesap sonuçlarının yanlış anlaşılması şeklinde bilançoda düzensizliğe yol açacak bir hata yapmadıklarını, \%95,5'i işletmelerin alacak ve borçlarının veya geçici aktif ve pasif hesaplarının birbirinden çıkarılması sonucu bazı hesapların bilançoda noksan olması şeklinde bir hata yapmadıklarını, \%79,1'i herhangi bir işlemin yevmiye defterlerinde tam ve doğru gösterilmesine rağmen büyük deftere aktarımı sırasında hesap ismi benzerliği veya başka nedenlerden ötürü yanlış hesaba kayıt yapmadıklarını, \%79,1'i mesleki hizmet konusunda çalışanlarının mesleki tecrübeye ve bilgiye sahip olmamalarına rağmen müşterilerin lehine hatalı işlemler gerçekleştirmediklerini, \%50,7'si müşterilerinin muhasebe bilgilerini zamanında göndermemesinden kaynaklanan hatalı bir işlem yapmadıklarını, \%85,1'i dikkatsizlik sonucu borç ve alacak hesaplarını karıştırarak hatalı bir işlem yapmadıklarını, \%52,2'si bilançoda işletmenin aktif hesaplarını daha iyi veya kötü gösterilmesini isteyen müşterinin olmadığını, $\% 89,6$ 'si benzer hesapların yanlış yerde kullanılmasından ötürü yanlış raporlama yapılmasını sağlamadığını, \%82,1'i gelecek yıla ait gelir ve giderlerin içinde bulunulan döneme kaydedilmesini isteyen müşterilerinin olmadığını, \%74,6'si gelir ve giderlerdeki tahakkuk etme esasının yanlış kullanılması sonucu bilanço karını yüksek veya düşük gösterilmesini isteyen müşterilerinin olmadığını, \%92,5'i uzmanlığı bulunmadığı bir alanda uzmanmış gibi davranarak müşteri kazanmadıklarını, \%52,2'si finansal tabloların gerçekliğini etkilemeyecek düzeyde sayısal hata veya işlem gerçekleştirmediklerini ifade etmişlerdir.

Bu kısımda elde edilen sonuçlar, Okay (2011)’ın elde ettiği sonuçlarla hemen hemen örtüştüğü söylenebilir. Ancak iki husus farklılık göstermektedir. Birincisi Okay (2011) çalışmasında muhasebe meslek mensuplarının tamamı müşterilerinin gerekli bilgileri istenilen zamanda göndermemesinden kaynaklı hata yapmadıklarını ifade etmişken, bu çalışmada katılımcıların aynı ifadeye verdikleri olumlu ve olumsuz cevaplar birbirlerine çok yakındır. İkincisi katılımcılar Okay (2011)'ın çalışmasında tüm ifadeler için baskın bir şekilde "Hayır" ifadesini tercih ederken, bu çalışmada böyle bir tercih söz konusu değildir. Bu durum katılımcıların zaman zaman çeşitli sebeplerden dolayı muhasebe hata veya hileleri yapmaya maruz kaldıkları şeklinde yorumlanabilir.

Muhasebe meslek mensuplarının muhasebede yapılan hata, hile ve meslek etiğine yönelik düşüncelerinin ve karşılaştıkları hata ve hilelerin meslek mensuplarının demografik özelliklerine göre farklılaşıp farklılaşmadığını belirlemek amacıyla geliştirilen hipotezler aşağıda analiz edilmiştir. Çalışmada sadece anlamlı farklılık bulanan hipotezlere yer verilmiştir.

H: Muhasebe meslek mensuplarmın tecrübeleri ile muhasebede hata, hile ve meslek etiğine yönelik düşünceleri arasında anlamlı bir fark vardır.

Tablo 5. Kruskal-Wallis Testi Analiz Sonuçlarına İlişkin Bulgular

\begin{tabular}{cccccc}
\hline $\begin{array}{l}\text { Mesleki } \\
\text { Tecrübe }\end{array}$ & $\mathbf{N}$ & $\begin{array}{c}\text { Sira } \\
\text { ortalamasi }\end{array}$ & $\mathbf{X}^{2}$ & sd & $\mathbf{p}^{*}$ \\
\hline 10 yıldan az & 14 & 39,96 & & \\
\hline
\end{tabular}




\begin{tabular}{cccccc}
\hline 11-20 yil arasi & 22 & 35,07 & 2,379 & 2 & 0,032 \\
\hline 21 yıldan fazla & 31 & 30,55 & & & \\
\hline
\end{tabular}

${ }^{*} \mathrm{p}<0,05$ anlamlı fark var; $\mathrm{p}>0,05$ anlamlı fark yok

Muhasebe meslek mensuplarının tecrübeleri ile muhasebede hata, hile ve meslek etiğine yönelik düşünceleri arasında $\% 5$ anlamlılık düzeyinde istatistiksel olarak anlamlı bir fark bulunmuştur $(p=0,000<\alpha=0,05)$. Yani $\mathrm{H}_{1}$ hipotezi kabul edilmiştir. Buna göre meslek mensuplarının tecrübelerinin sıra ortalamalarına bakıldığında, tecrübesi 10 yıldan az olan $(39,96)$ meslek mensuplarının muhasebede hata, hile ve meslek etiğine yönelik düşüncelerinin daha olumlu olduğu söylenebilir.

Bu durum mesleki tecrübesi az diğer bir ifadeyle daha genç meslek mensuplarının mesleklerinde bu tür davranışları doğru bulmamalarının sebebi olarak; son yıllarda özellikle hile ve meslek etiği ile alakalı eğitimlere ağırlık verilmesi ve bu konularla ilgili mesleki kuruluşların çeşitli düzenlemelere ön ayak olması sayesinde genç meslek mensuplarında bir farkındalık oluşturduğu şeklinde açıklanabilir.

$\mathrm{H}_{2}$ : Muhasebe meslek mensuplarının tecrübeleri ile karşılaştıkları hata ve hileler arasında anlamlı bir fark vardir.

Tablo 6. Kruskal-Wallis Testi Analiz Sonuçlarına İlişskin Bulgular

\begin{tabular}{|c|c|c|c|c|c|}
\hline Mesleki Tecrübe & $\mathbf{N}$ & Sira ortalaması & $X^{2}$ & sd & $\mathbf{p}^{*}$ \\
\hline 10 yıldan az & 14 & 28,68 & \multirow{3}{*}{6,322} & \multirow{3}{*}{2} & \multirow{3}{*}{0,042} \\
\hline $11-20$ yıl arası & 22 & 28,43 & & & \\
\hline 21 yıldan fazla & 31 & 40,35 & & & \\
\hline
\end{tabular}

${ }^{*} \mathrm{p}<0,05$ anlamlı fark var; $\mathrm{p}>0,05$ anlamlı fark yok

Muhasebe meslek mensuplarının tecrübeleri ile karşılaştıkları hata ve hileler arasında \%5 anlamlılık düzeyinde istatistiksel olarak anlamlı bir fark bulunmuştur $(\mathrm{p}=0,000<\alpha=0,05)$. Yani $\mathrm{H}_{2}$ hipotezi kabul edilmiştir. Buna göre meslek mensuplarının tecrübelerinin sıra ortalamalarına bakıldığında, tecrübesi 21 yıldan fazla olan $(40,35)$ meslek mensuplarının karşılaştıkları hata ve hilelerin daha fazla olduğu söylenebilir.

Burada öncelikle şu konu ifade edilmeli; iki değişken arasında hipotez kurulurken literatürden destek alınır veya değişkenler arasında mantıklı bir ilişkinin olması beklenir. Dolayısıyla meslek mensuplarının hizmet yılları ile karşılaştıkları hata veya hileler arasında doğrusal bir ilişkinin olması beklenir. Nitekim bu çalışmada elde edilen bulgu da bu varsayımı destekler niteliktedir. Ancak 10 yıldan az tecrübeye sahip olanların ortalaması, tecrübesi 11-20 yıl arasında olan meslek mensuplarının ortalamasından azda olsa yüksek olduğu görülmektedir. Bu durumda beklenilen ilişkinin tam olarak ortaya çıkmadığı şeklinde değerlendirilebilir.

\section{SONUÇ}

Muhasebe insanlığın hayatını devam ettirebilmesi için olmazsa olmaz bir unsur olan para ile ilgili işlemlerin gerçekleştirilerek, elde edilen bilgilerin üçüncü kişilere sunulmasını sağlayan bir disiplindir. Bu bağlamda, muhasebe bilgileri muhasebenin sosyal sorumluluk kavramının bir 
gereği olarak güvenilir, tarafsız, ilgili ve tutarlı olmalıdır. Diğer bir ifadeyle bu bilgiler, mali nitelikteki alınacak kararlarda etkili olduğu için nitelikli olması gerekir. Çünkü muhasebenin üretmiş olduğu bilgilerden başta devlet olmak üzere, işletmeler, işletme sahipleri, kredi kuruluşları, yatırımcılar gibi birçok kesim faydalanmaktadır. Dolaysıyla muhasebe sürecinde yürütülen tüm faaliyetlerde ve bu süreç üzerinde söz sahibi olan tüm taraflarda meslek etiği büyük önem taşımaktadır. Muhasebe mesleğinde meslek etiği üzerinde etkili olan başlıca iki faktör vardır. Bunlar; muhasebe hata ve hileleridir. Muhasebe hilelerinde bilinçli yapılan eylemler söz konusuyken hatalarda, bilinçli eylem ve kasıt söz konusu değildir. Bir başka ifadeyle, muhasebe hilelerini muhasebe hatalarından ayıran en önemli husus kasıt olup olmamasıdır. Özellikle daha az vergi ödeyebilmek amacıyla bu tür meslek etiği dışı eylemlere başvurulduğu söylenebilir. Bunu da muhasebe meslek mensupları ya kendi menfaatleri için ya da müşterilerinin taleplerine karşı koyamadıkları için yaptıklarını söylemek mümkündür.

Günümüzde muhasebe hata ve hilelerinin en çok hangi amaçlarla ve şekilde yapıldığını en iyi gözlemleyen kişilerin muhasebe meslek mensuplarının olduğu aşikârdır. Bu durumdan hareketle, muhasebede yapılan hata ve hilelerin meslek etiği açısından değerlendirilmesi ve muhasebe meslek mensuplarının söz konusu hususlara ilişkin görüşlerinin ortaya konulması bu çalışma ile amaçlanmıştır. Ayrıca muhasebede hata ve hilelerin nedenlerini ve muhasebe meslek mensuplarını hata ve hile yapmaya yönelten etkenlerin neler olduğunu belirlemek çalışmanın bir diğer amacını oluşturmaktadır. Bu kapsamda, Erzincan'daki Serbest Muhasebeci Mali Müşavirler Odası'na kayıtlı ve aktif olarak çalışan muhasebe meslek mensuplarına bir anket uygulanmıştır. Anketlerden elde edilen veriler üzerinde yapılan analiz sonuçları aşağıda genel olarak özetlenmiştir.

Elde edilen bulgulara göre, muhasebede yapılan hataların en temel sebebinin iş yoğunluğundan kaynaklandığı ve bilançoda aktif hesapların olduğundan daha iyi gösterilmesinin amacı kredi kuruluşlarından daha fazla kredi almak olduğu tespit edilmiştir. Ayrıca muhasebe meslek mensupları işlerini yaparken meslek ahlak kurallarına uygun olarak hareket ettiklerini fakat meslek ahlakına uymayan davranış veya işlem yapanlara verilen cezaların düşük olduğu düşüncesine sahip oldukları görülmüştür. Çalışmada elde edilen bir diğer sonuç, meslek ahlakı çerçevesinde yasal çalışmaların yetersiz olduğu, mevcut denetim sistemi ve vergi uygulamalarının muhasebede hata ve hilelerin önüne geçmede yeterince etkili olmadığı ve merkezi bir etik kurulunun kurulması gerektiği ifade edilmiştir. Son olarak muhasebe meslek mensuplarının tecrübeleri ile muhasebede hata, hile ve meslek eğitine yönelik düşünceleri ve karşılaştıkları hata ve hileler arasında anlamlı bir farklılık olduğu tespit edilmiştir. Elde edilen sonuçlar genel olarak literatürde yapılan benzer çalışmaların sonuçlarıyla paralellik göstermektedir.

Günümüzde yaşanan ekonomik ve teknolojik gelişmeler göz önünde bulundurulduğunda, muhasebecilik mesleği giderek daha yoğun ve dikkat gerektiren bir iş yükü olan, daha çok bilgi ve analitik düşünceyi gerektiren süreçlerin olduğu bir meslek haline gelmiştir. Ancak gerek bu çalışmada gerekse literatürdeki benzer çalışmalarda muhasebe meslek mensuplarının dikkatsizliklerinden ve yeterli bilgi düzeyine sahip olmamalarından kaynaklı muhasebe hatalarının yapıldığı görülmektedir. Bu durumda meslek etiğini olumsuz yönde etkilemektedir. Burada şunu da ifade etmekte fayda vardır. Her ne sebeple olursa olsun muhasebe meslek mensubu mesleğinin gerektirdiği azami özeni ve titizliği göstermeli ve meslek etiğinin dışına çıkmamalıdır. Bunların sağlanabilmesi düzenleyici kurum veya kuruluşlar tarafından hazırlanan meslek ahlak kurallarının benimsenmesine, fiili olarak uygulanmasına ve takibine bağlıdır. Burada istenilen başarının sağlanabilmesi her ne kadar yasal düzenlemelere bağlı olsa da kişilerin ahlaki değer yargıları diğer bir ifadeyle vicdani sorumlulukları da önemli bir rol oynamaktadır. 
Özetle, muhasebe mesleğinde meslek etiğini olumsuz etkileyen muhasebe hata ve hilelerinin önüne geçilebilmesi bu konuyla ilgili yapılacak yasal düzenlemelere ve özellikle gerek bireysel gerekse toplumsal ahlak düzeyinin artırılmasına bağlıdır.

\section{KAYNAKÇA}

ACFE, (2010). "2010 Acfe Report to the Nation of Occupational Fraud\&Abuse. Association of Certified Fraud Examiners", Austin, USA.

Ahinful, G.S., S. Addo, F.O. Boateng ve J.D. Boakye. (2017). Accounting Ethics and the Professional Accountant: The Case of Ghana. International Journal of Applied Economics, Finance and Accounting, 1 (1), 30-36.

Akbaş H.E., Çalışkan A. ve Özarslan E. (2009). “Muhasebe Mesleğinde Etik Algısı ve Etik Dışı Davranışlarla İlişkisi: İşletme Bölümü Öğrencileri Üzerine Bir İnceleme". Marmara Üniversitesi Sosyal Bilimler Enstitüsü Dergisi, 8 (32), 175-184.

Aktekin, Ü. (2019). Muhasebe Denetiminde Karşılaşılan Hileler ve Meslek Mensuplarının Tutumu: Bingöl ve Elazığ Örneği. Bingöl Üniversitesi Sosyal Bilimler Enstitüsü Yayınlanmamış Yüksek Lisans Tezi, Bingöl.

Alagöz A. (2008). İşletmelerde İç Kontrol Sisteminin Önemi ve Denetim Komiteleri ile İç Denetim Birimi İlişkisinin Hata ve Hilelerin Önlenmesindeki Rolü. Güncel İşletmecilik Konuları, Konya: Tablet Yayınları.

Aslan T., Kızıl C. ve Din A. (2017). "Muhasebe Hata ve Hileleri Üzerinde Etkili Faktörlerin Muhasebe Meslek Etiği Kapsamında Analizi: Yalova Örneği". Journal of Social and Humanties Sclences Research, 4 (12), 1125-1138.

Aymankuy Y. ve Sarığlan M. (2010). “Muhasebe Meslek Mensuplarının Meslek Etiğine Yaklaşımları ve Balıkesir İl Merkezinde Bir Uygulama". Balıkesir Üniversitesi Sosyal Bilimler Dergisi, 8 (14), 23-45.

Aytekin S., Sezgin H. ve Yalçın M. (2015). “Uygulamacıların Muhasebe Hata ve Hileleri ile Hile Belirteçlerine Yönelik Yaklaşımları: Balıkesir İli Örneği". Muhasebe ve Denetime Bakış Dergisi, 14 (44), 69-89.

Azaltun, M. ve Kaya, E. (2006). Muhasebe Eğitiminde Meslek Etiğinin Yeri ve Önemi: Anadolu Üniversitesinde Yapılan Bir Araştırma. MODAV Muhasebe Bilim Dünyası Dergisi, 8 (1), 107126.

Baskan, D. (2013). Muhasebe Hata ve Hilelerin Önlenmesinde Bağımsız Denetimin Rolü ve Etkinliği: Bir Uygulama. Kırıkkale Üniversitesi Sosyal Bilimler Enstitüsü Yayınlanmamış Doktora Tezi, Kirıkkale.

Bayraktar M. (2019). Muhasebe Hata ve Hilelerinin Muhasebe Bilgi Sistemi Üzerine Etkileri ve Meslek Mensuplarının Muhasebe Hata ve Hilelerine Bakış Açılarının Değerlendirilmesine Yönelik Bir Araştırma: Sivas Örneği. Sivas Cumhuriyet Üniversitesi Sosyal Bilimler Enstitüsü Yayınlanmamış Yüksek Lisans Tezi, Sivas.

Bayraktaroğlu H. (2016). "İşletmelerde Muhasebe Hata ve Hilelerinin Önlenmesinde Etkin Muhasebe İç Denetiminin Rolü ve Önemi Üzerine Bir Alan Araştırması". Muhasebe Bilim Dünyası Dergisi, 18 (1), 185-214.

Bierstaker, J.L., R.G. Brody ve C. Pacini. (2006). Accountants' Perceptions Regarding Fraud Detection And Prevention Methods. Managerial Auditing Journal, 21 (5),520-535. 
Bozkurt N. (2011). İşletmelerin Kara Deliği: Hile Çalışan Hileleri. (2. Basım), İstanbul: Alfa Yayınları.

Çelik T. (2010). Muhasebede Hata ve Hileler ile İlgili Muhasebe Meslek Mensupları Üzerinde Bir Araştırma. Niğde Üniversitesi Sosyal Bilimler Enstitüsü Yayınlanmamış Yüksek Lisans Tezi, Niğde.

Dinç Y. ve Cengiz S. (2014). "Muhasebe Denetiminde Hata ve Hilenin Denetçi Etiği Açısından İncelenmesi: Enron Skandalı Örneği". Çankırı Karatekin Üniversitesi Sosyal Bilimler Enstitüsü Dergisi, 5 (1), 221-236.

Dumanoğlu S. (2005). “Hata ve Hile Ayrımı: Hile Denetimi”. Marmara Üniversitesi İ.İ.B.F Dergisi, 20 (1), 347-358.

Erol, M. (2008). İşletmelerde Yaşanan Yolsuzluklara (Hata Ve Hileler) Karşı Denetimden Beklentiler. Süleyman Demirel Üniversitesi İktisadi ve İdari Bilimler Fakültesi Dergisi, 13 (1), 229-237.

Gümüş U. ve Göğebakan H. (2016). “Muhasebede Hata ve Hileleri ile Muhasebe Mesleğinde Etik, Aydın İlinde Muhasebeciler Üzerine Bir Araştırma". Uluslararası İşletme, Ekonomi ve Yönetimi Perspektifi Dergisi, 1 (3), 12-27.

Güney S. ve Çınar O. (2012). “Serbest Muhasebeci Mali Müşavirlerin (SMMM) Etik Algıları: Erzurum Örneği". Atatürk Üniversitesi İktisadi ve İdari Bilimler Dergisi, 26 (2), 91-106.

Holmes Arthur W. ve Wayne S. (1975). Muhasebe Denetimi Standartları ve Yöntemleri. (8. Basım), (Çev. Oğuz Göktürk). Bilimsel Yayınlar Derneği, Yayın No: 5.

https://erzincansmmmo.org.tr/uye-listesi/

Irmak R., Kurnaz G., Çağlayan B. ve Bal, B. (2002). Muhasebenin Genel Esasları Muhasebe Hata ve Hileleri ile Bunların Tespit Yöntemleri. Ankara: Şafak Matbaacılık.

Karabayır, M. E., Öztürk S.ve Cengiz. S. (2018). Muhasebe Meslek Mensubu Adayları ve Etik İkilem. Muhasebe ve Vergi Uygulamaları Dergisi, Özel Sayı, 328-353.

Kaval, H. (2005). Uluslararası Finansal Raporlama Standartları Uygulama Örnekleri İle Muhasebe Denetimi. Gazi Kitapevi, Ankara.

Kirik Z. (2007). Muhasebe Hata ve Hileleri ile Muhasebe Mesleğinde Etik: Afyonkarahisar'da Muhasebeciler Üzerine Bir Araştırma, Anadolu Üniversitesi Sosyal Bilimler Enstitüsü Yayınlanmamış Yüksek Lisans Tezi, Eskişehir.

Kirkos E., C. Spathis ve Y. Manolopoulos. (2007). Data Mining Techniques For The Detection Of Fraudulent financial Statements. Expert Systems with Applications 32, 995-1003.

Korucu, E. (2017). Muhasebede Hata ve Hileleri ile Muhasebe Mesleğinde Etik, Işık Üniversitesi Sosyal Bilimler Enstitüsü Yayınlanmamış Yüksek Lisans Tezi, İstanbul.

Kula, V., Kaynar, B. ve Keskin Köylü, M. (2008). Hileli Finansal Raporlama Yaklaşımlarını Belirleyen Teşvikler/Baskılar ve Fırsatlar. Muhasebe ve Denetime Bakış Dergisi, 25, 63-82.

Kutluk F.A. ve Ersoy A. (2011). “Muhasebe Meslek Mensuplarının Etik Yargı Düzeylerine Üzerine Bir Araştırma". Ege Akademik Bakış Dergisi, 11 (3), 425-438.

Okay S. (2016). “Muhasebe Hata ve Hilelerinin Meslek Etiği Yönünden İncelenmesi: Diyarbakır Örneği". Uluslararası Sosyal Araştırmalar Dergisi, 9 (44), 1151-1165. 
Özçelik H., Karakaş Aracı Ö. ve Keskin S. (2017). “Muhasebe Hata ve Hileleri: Meslek Mensupları Üzerine Bir Araştırma". Süleyman Demirel Üniversitesi Sosyal Bilimler Enstitüsü Dergisi, 29 (49), 197-214.

Özçelik, H ve Keskin, S. (2017). Muhasebe Meslek Etiği ve Uygulamaları: Batı Akdeniz Bölgesinde Bir Araştırma. Mehmet Akif Ersoy Üniversitesi İktisadi ve İdari Bilimler Fakültesi Dergisi, 4 (2), 138-150.

Ramos M. (2003). Auditors'Responsibility for Fraud Detection.Erişimadresi http://www.journalofaccountancy.com/issues/2003/jan/auditorsresponsibilityforfrauddet ection.htm.

Sakarya G. ve Kara S. (2010). “Türkiye'de Muhasebe Meslek Etiğine Yönelik Düzenlemeler ve Meslek Mensupları Tarafından Algılanması Üzerine Bir Alan Araştırması". KMÜ Sosyal ve Ekonomik Araştırmalar Dergisi, 12 (18), 57-72.

Selimoğlu S. (1997). “Muhasebe Denetimi Mesleğinde Yetkiler, Sorumluluklar ve Meslek Ahlakı”. Muhasebede Meslek Ahlakı Yaklaşımı, III. Türkiye Muhasebe Denetimi Sempozyumu, İSMMMO Yayınları.

Sözbilir, N. (2000), Türkiye'de Muhasebe Uygulamalarında Etiksel Boyutlar. Afyon Kocatepe Üniversitesi.

Tavşancıl, E. (2005). Tutumların Ölçülmesi ve SPSS ile Veri Analizi. Ankara: Nobel Yayın Dağıtım.

TESMER (2010). Meslek Hukuku, Mesleki Değerler ve Etik. Temel Eğitim ve Staj Merkezi Yayınları: 88, Ankara.

Tükenmez M. ve Kutay N. (1998). "Muhasebe Mesleğinde Meslek Ahlakının Yeri ve Önemi”. Yönetim ve Ekonomi Dergisi, 4 (1), 441-452.

TÜRMOB, (2007). “Serbest Muhasebeci Mali Müşavirler ve Yeminli Mali Müşavirlerin Mesleki Faaliyetlerinde Uyacakları Etik İlkeler Hakkında Yönetmelik". https://www.turmob.org.tr/Arsiv/FCKEditor/userfiles/file/Yonetmelik_MMKarari_Yasa_ 10_4_2018/13-Etik\%20ilkeler\%20Hak_Yonetmelik.pdf, (Erişim Tarihi: 15. 05. 2020)

www.kgk.gov.tr, (Erişim Tarihi: 14.05.2020)

Yaman T. (2008). Finansal Tablolar Aracılı̆̆ı ile Kullanıcılara Yanıltıcı Bilgi Sunulması ve Sonuçları. Marmara Üniversitesi Sosyal Bilimler Enstitüsü Yayınlanmamış Doktora Tezi, İstanbul. 